\title{
'It's not just the learner, it's the system!' Teachers' perspectives on written language difficulties: Implications for speech-language therapy
}

\author{
Indira Navsaria \\ Michelle Pascoe \\ Harsha Kathard \\ Department of Health and Rehabilitation Sciences, University of Cape Town
}

Correspondence to: I Navsaria (indira.navsaria@gmail.com)

\begin{abstract}
The failure to achieve academic outcomes in linguistically diverse classrooms in poor areas of the Western Cape, South Africa, is well documented. A major contributing factor is the written language communication difficulties experienced in these classrooms. This paper describes the views of intermediate-phase teachers on why written language difficulties are experienced by learners and ways in which these difficulties might be overcome. A series of interviews were conducted with two class teachers in one urban school from which there had been a high number of referrals for speech-language therapy. The teachers were individually interviewed using an in-depth, semi-structured format. Teachers reported that $50-70 \%$ of learners in their classes were not meeting grade level academic outcomes. They were asked to explain the difficulties experienced with regard to written language, and the challenges and solutions linked to these. The findings suggest that there are barriers and opportunities at the school system, individual learner and home/social community levels. Major challenges identified at the school system level included limited training and lack of support for teachers, poor foundation skills in learners and difficulties with language. The current opportunities for the development of written language were insufficient and teachers identified further opportunities to promote the learners' written language development. These included training and support for teachers, clear and consistent assessment guidelines, remedial assistance for learners and safe, nurturing home environments. There is a need to look beyond the learner as the site of the problem; a systemic approach is essential. In the light of these findings, suggestions are made for the role of the speech-language therapist.
\end{abstract}

Keywords: classrooms, linguistic diversity, speech-language therapists, teachers, Western Cape, written language

The impetus for this study was the high number of referrals that speechlanguage therapists (SLTs) based at a newly established university clinic in the Cape Flats area of the Western Cape had received. There were no SLT services in this poor community prior to the establishment of the university clinic in 2004. When teachers were informed of the service available to assist learners with communication difficulties, they referred learners in large numbers. The majority of learners were from intermediate-phase classrooms, and reported to be experiencing problems with written language. The situation warranted further investigation, and a project was therefore initiated to understand the challenges and to explore possible intervention strategies. This paper focuses specifically on teachers' perspectives on written language expression in intermediate-phase learners in an urban ordinary school in the Cape Flats area of the Western Cape, South Africa.

The term 'ordinary' is used to refer to classrooms in mainstream government schools and not to classrooms in 'special schools' (DoE, 2001, p.15). Intermediate phase refers to grades $4-6$ in these ordinary schools. Written language may be defined as a set of phonological (sounds), syntactical (form) and semantic (content/meaning) rules represented by orthographic features (Nicolosi, Harryman \& Krescheck, 1989 , p. 142). It also refers to reading, writing and related processes (ASHA, 2001, p. 355). Written language expression refers to the written language texts that are generated through the writing processes as a form of communicating meaning to the reader (ASHA, 2001, p. 169).

While the problem was highlighted at a localised site, the reading and writing difficulties of children throughout South Africa are well documented (Centre for Evaluation and Assessment, 2006; DoE, 2008). In 2003, the South African Department of Education (DoE) investigated literacy levels among grade 3 learners and found that $61 \%$ of children did not have age-appropriate reading and writing skills (Centre for Evaluation and Assessment, 2006). The Progress in International Reading Literacy Study (PIRLS) reported results from South Africa which showed the lowest reading literacy levels of all 40 countries investigated (Mullis, Martin, Kennedy \& Foy, 2007) despite the fact that the South African grade 5 learners were compared to grade 4 learners internationally (Scherman, van Staden, Venter \& Howie, 2008). South African learners were found to be more than two grades behind their international peers as regards reading. As reading and written language are closely related, it is likely that their written language skills would also be compromised. Reading and writing are important tools in other learning areas in later grades, so it is vital that effective interventions take place to help these children (Centre for Evaluation and Assessment, 2006). Current research by the Western Cape Education Department (WCED) confirms the concern about written language and reading, which has been described as a national crisis (DoE, 2008).

\section{The South African context: a historical perspective}

The current education crisis must be understood in the context of South Africa's history. In its second decade of democracy, South Africa's transformation of basic education is still underway and the vestiges of apartheid still hamper children's ability to learn (Nelson Mandela Foundation, 2004). Relevant to this study is that apartheid effectively divided education, had a language policy built for separate development, unequal resources and a cognitively impoverished curriculum that resulted in the majority of the population being undereducated (Heugh, 2000).

Post apartheid, one of the most dramatic changes that occurred as a consequence of the Schools Act in South Africa was racial desegregation, which resulted in the migration of learners. The flow of learners mimicked the apartheid racial hierarchy: African learners migrated to schools that had previously been open only to Indian, white or coloured children, while coloured learners migrated to Indian and white schools, and Indian learners moved to white schools (Pluddemann, Xola \& Mahlahela-Thusi, 2000). Classrooms became linguistically diverse a cause for celebration - yet with no redeployment of appropriately qualified African-language speaking teachers to the relevant schools, communication difficulties between teachers and learners have arisen (Pluddemann et al., 2000). In the community in which this study 
was conducted, African learners had migrated to previously coloured schools. As a consequence, learners as well as teachers frequently came from different language backgrounds, resulting in diverse languages in the classroom (Walton, 2002). However, the language of learning and teaching (LoLT) remained English, resulting in many learners learning in a foreign language, i.e. a language that is not their home language and which is often unknown to them as they had little exposure to English outside of school. This situation has created numerous teaching and learning challenges contributing to low achievement.

Added to the communication challenges is that many of these previously black and coloured schools continue to be overcrowded and underresourced. Basic amenities and infrastructures have still not been put in place, while previous white-only schools continue to be relatively well resourced (Soudien, 2008). In impoverished communities, such as the community in this study, teachers continue to encounter a large number of learners with many socio-economic problems that contribute to their learning difficulties. In both rural and poor urban schools there is a shortage of classrooms, teachers, and basic educational tools like stationery and textbooks, combined with poor basic needs like water and electricity (Nelson Mandela Foundation, 2004).

\section{Written language}

The overall purpose of writing is to communicate ideas. Spoken language provides a critical foundation for the development of reading and written language, and this relationship is reciprocal (Bishop \& Clarkson, 2003; Locke, Ginsborg \& Peers, 2002). Written language, together with spoken language and reading, contributes to the process of literacy (ASHA, 2002). Written language expression (production) is comprised of two stages, viz. the process and the product (ASHA, 2001). Writing processes include the cognitive-linguistic and motor acts that are involved in producing written language texts. These include planning (prewriting), organising, drafting, reflecting, revising and editing, as well as forming letters and sequences of letters into words. Written language is an important tool for learning as well as assessing learners in the classroom. With regard to the pass/fail criterion for learners in South African schools, oral communication accounts for approximately one-third of the total mark for English language (Kapp, 2004). In contrast, written language accounts for two-thirds of the total, signalling the high value placed on written language. Learners must have adequate written language skills in order to pass a grade, complete school and ultimately obtain employment.

\section{Teachers' perspectives}

O'Connor and Geiger (2009) described the challenges facing primary school educators of English second (or other) language (ESOL) learners in both advantaged as well as disadvantaged schools in the Western Cape. Their study used a self-administered questionnaire as well as focus groups to explore the attitudes and perceptions of grade 1, 2 and 3 teachers working with ESOL learners in schools in the region. These teachers described a shortage of educators able to speak isiXhosa, the most frequently occurring first (or home) language of the region's English second-language learners. Challenges faced by educators when teaching these learners included learners' academic and socioemotional difficulties and a lack of parent involvement. Participant educators indicated a need for departmental, professional and parental support, and additional training and resources.

Wium, Louw and Eloff (2010) also turned their attention to educators in the South African context, developing a continued professional development (CPD) programme for foundation-phase educators in a rural and township context. These authors describe the challenges facing these educators that have been documented in the literature, e.g. implementing a 'new' curriculum (Gouws \& Dicker, 2006), coping with the legacy of apartheid and managing a linguistically diverse classroom. The studies of O'Connor and Geiger (2009), and Wium et al. (2010) focused on educators in the foundation phase. In contrast, limited research has been carried out with educators in the intermediate phase, i.e. grades $4-6$. One such study is that by Botes and Mji (2010), which focused on linguistically diverse grade 4, 5 and
6 classrooms and specifically looked at the teaching of mathematics. The authors investigated whether a multilingual visual aid (similar to a mathematical 'dictionary') was able to enhance the performance of learners. They were able to demonstrate the effectiveness of this tool in their quasi-experimental study, and the comments of educators also supported the use of that strategy.

The present study focused on written language in the intermediate phase since it was in this phase that teachers were reporting significant concern about learners' literacy skills which are critical in the assessment of all learning areas, including mathematics (as described by Botes and $\mathrm{Mji}, 2010$ ). Academic language learning problems frequently become visible as basic literacy skills are applied and the day-to-day demands of the classroom intensify. The long-term result of poor reading and writing skills among young learners is that they leave primary school with low literacy levels, and face ongoing problems in secondary school, as evidenced by the poor matric results (UNESCO, 2010). Negative long-term outcomes have been linked to limited support received in schools (DoE, 2001). Education White Paper 6, the policy document on inclusive education and training system in South Africa, states that $70 \%$ of learners in mainstream education who experience barriers to learning receive little or no educational support (DoE, 2001).

SLTs have the expertise and knowledge to assist with communication difficulties of all kinds. It has been argued that they should be involved in supporting teachers and learners in linguistically diverse classrooms to enhance communication and promote literacy learning among the learners (Du Plessis \& Louw, 2008; Wium, 2010). However, in order to propose intervention relevant to the context, an in-depth understanding of teachers' perspectives is required. This study therefore focused on two intermediate-phase educators in one school, asking: 'What are teachers' concerns about written language? What are the challenges and what are some of the ways in which these might be addressed?'

\section{Method}

\section{Aims}

The study aimed to describe:

1. Teachers' perceptions of the learners' written language expression.

2. Teachers' perceptions of the challenges affecting the development of written language.

3. Teachers' perceptions of the opportunities to develop the written language of the learners.

\section{Research design}

An exploratory, inductive case study research design was used to: (i) satisfy the researchers' desire to gain a better understanding of the issues surrounding written language; (ii) generate ideas for a more extensive study and establish priorities for future research; and (iii) develop new interpretations or theories of certain areas of interest (Sofaer, 2002). The study was an in-depth investigation of teacher, learner and parent perspectives on why learners were not achieving grade-level outcomes for written language. However, this paper focuses specifically on teachers' perspectives of written language expression in intermediatephase learners in an urban ordinary school in the Cape Flats area in the Western Cape, South Africa. This study investigated written language through the eyes of classroom teachers using individual semistructured interviews.

This study was conducted in accordance with the Declaration of Helsinki (World Medical Association, 2008). Confidentiality was maintained and each participant had to be legally competent and informed before they were invited to voluntarily sign a consent form. No incentives were given for participating in this study. The privacy accorded to the participants gave them freedom to speak openly about their views, and by opting for individual interviews, a polarisation effect was avoided (Maxwell \& Satake, 2006).

\section{Participants}

Two teachers from the same school participated in the study. Their accounts provided rich data allowing for in-depth analysis. Typical case 
sampling, a form of purposive sampling, illustrates what is typical in a specific context (Patton, 2002). The school is situated in the socioeconomically disadvantaged Cape Flats area in Cape Town, South Africa, where violence and crime are prevalent. Politically, it was classified as a coloured area in apartheid South Africa where people of mixed race resided.

Inclusion criteria for teacher participants were:

- currently teaching in the intermediate phase in a linguistically diverse classroom

- teaching language and one other learning area that included written language (e.g. history/geography/science)

- a minimum of 3 years' teaching experience in linguistically diverse classrooms

- willingness to participate and the ability to reflect on languagerelated issues

- to have previously reported written language as a challenge.

The two form teachers of the grade 5 and 6 classrooms were selected as they were involved in teaching all learning areas except art. The investigation was limited to two participants because of the in-depth, qualitative nature of the study. Table I summarises the biographical information about the teachers.

\section{Materials and procedure}

Permission was requested from the WCED to conduct the study at the relevant school. The study was approved by the University of Cape Town Faculty of Health Sciences Human Research Ethics Committee (REC REF: 460/2007). The school principal and the chairperson of the school governing body (SGB) were contacted for permission to conduct the research with teachers. The teachers were interviewed individually at the school during their free period, a time in which they were not teaching. The interviews took place in the school staff room and also in the classrooms. The rooms were quiet and private with minimal interruptions. The teachers were interviewed formally in a semistructured interview format which ranged from 90 to 120 minutes. Follow-up discussions then took place over a period of 6 months following the main interview. These follow-up discussions ranged from 30 to 60 minutes and typically took place in the classrooms, again on an individual and private basis. The formal interviews were audiorecorded while field notes were made during the ongoing discussions. The main question was about the difficulties experienced by the learners in the classes with regard to written language, and the challenges and solutions linked to these. The topic areas used in the semi-structured interviews are listed in Appendix A. However, the interviewer and teachers had the freedom to deviate from the planned structure of the interview in order to explore a particular subject of interest in more depth using elaboration, clarification and continuation probes (Rubin \& Rubin, 2005).

A number of steps were taken to ensure trustworthiness and rigour of the research. Dependability was accomplished through careful documentation of procedures for generating and interpreting data. Peer debriefing was done with the supervisors of this study. In order to ensure credible/valid data, main interviews were audio-recorded. Participants were asked to select a language they were comfortable with. Predefined questions and procedures were used with both participants. There had to be a degree to which interpretations and theories were shared by the participants and the researcher (Rubin \& Rubin, 2005). Therefore, the researcher attempted to clarify any misunderstandings during the interviews to ensure that the participants' responses were correctly interpreted by the interviewer. The researcher transcribed the interviews. The transcriptions were typed verbatim according to the audio tapes using a computer and Microsoft Office Word. The researcher then cross-checked all the transcriptions with the audio recordings to verify accuracy of the transcriptions. Finally, the transcripts were checked by an experienced SLT who had no vested interest in the study. There was $99 \%$ agreement between the researcher's and the proofreader's transcriptions.

\section{Analysis}

The researcher read the transcripts several times to become totally familiar with the data. Data collection and ongoing analysis took place over the next 5 months before the final analysis took place (Rubin \& Rubin, 2005). The next stage of analysis was recognition, in which concepts, themes, events and topical markers in the interviews were found (Rubin \& Rubin, 2005). The researcher read the transcriptions to note core ideas and concepts, recognise emotive stories and find themes (Rubin \& Rubin, 2005). The themes obtained from the data were then sorted to determine which ones were related in order to answer the research questions. Peer review took place throughout the analysis process to discuss and verify results. Saturation was reached when the researcher had become fully immersed in the phenomenon being studied in order to achieve complete understanding (Maxwell \& Satake, 2006). Saturation implies that a researcher has performed a deep or dense description in an effort to extract as much meaning from the data as possible and further information becomes redundant and repetitive (Maxwell \& Satake, 2006).

\section{Results}

\section{Teachers' perceptions of the learners' written language expression}

The teachers had many concerns regarding the learners' written language performance. Teacher 1 estimated that $70 \%$ of the learners in her grade 5 class were not meeting the written language outcomes for the grade, while only $30 \%$ of the learners were able to write coherently.

\section{T1: 'Very, very bad, I'm very concerned. I'm doing what I can do but I'm very concerned.'}

Learners need to be able to write a cohesive story with good punctuation and paragraphs in both grades 5 and 6 . However, the teachers need to focus on the content of the story and not on the spelling of words, which it is assumed that they can do already. Teacher 1 stated that the learners struggled with all aspects of written work: spelling, punctuation, and reading and written comprehension.

T1: 'They should have good punctuation, good cohesion and paragraphs, but they don't. I'm supposed to be introduced to average punctuation and good cohesion. Because in grade 4 they are taught how to link sentences and how sentences are supposed to run into each other, you know like a story that kind of thing, but they have a story lacking.'

Teacher 2 reported that $50 \%$ of the learners in his grade 6 class were not meeting the written language outcomes for the grade and were not able to write coherently. He also reported that sentence construction was poor.

T2: 'Fifty per cent (50\%) of the class are not up to standard with their written language, creative writing or any kind of writing for that matter. It seems to me that it's difficult for them to put pen to paper when it comes to their own thoughts and ideas. They just can't write cohesively.'

\section{Table I. Biographical details of teacher participants}

\begin{tabular}{|c|c|c|c|c|c|c|c|}
\hline Initials & Grade taught & Years of experience & Qualifications & Race & Sex & Age & Language spoken \\
\hline $\mathrm{T} 1$ & 5 & 21 & Honours degree in education & Coloured & $\mathrm{F}$ & 45 & English and Afrikaans \\
\hline $\mathrm{T} 2$ & 6 & 10 & Honours degree in education & Coloured & M & 46 & English and Afrikaans \\
\hline
\end{tabular}


A concern is that if learners continue to fail to meet the writing outcomes, they may not be able to catch up, and the gap between the learners and the required outcomes will persist. These learners will enter high school not having met the writing outcomes for primary school. Learners may not be able to cope with the national matriculation examination. Matriculation failure rates mean poor employment prospects as learners are not able to pursue further tertiary education.

In this study, both teachers identified large number of learners as experiencing written language difficulties. All learners were affected, i.e. ESOL learners as well as English first-language learners. Written language development is a general concern and not specific to ESOL learners.

\section{Teachers' perceptions of the challenges affecting the de- velopment of written language}

The teachers identified major challenges that were hampering written language development in learners. These were grouped into three main levels: (A) a school system level; (B) an individual learner level; and (C) a social/home community level.

\section{A. Barriers at the school system level}

The majority of the challenges identified were at the school system level. Both teachers emphasised the systemic barriers that affect the written language of the learners:

T1: 'Because of systemic problems $70 \%$... bad, only 30\% of my children can write coherently. I can prove it.'

T2: 'I came through the system, the old system and I'm in the new system. I think we've thrown out the good of the old system. Writing, reading, doing your basic 1, 2, 3's, your reading, your writing.'

Specific barriers relating to the school system are discussed below.

\section{Lack of inclusive education practice}

Teacher 1 tried to apply the principles of inclusive education in her classroom as she understood that many learners came into her classroom with language, visual or emotional barriers. She tried to accommodate these barriers when carrying out her assessments. For example, as she was aware that many learners struggled with written language and reading, but were good oral language communicators, she allowed learners to do oral presentations and posters when assessing them in the different learning areas. However, not all teachers in the school do this and therefore inclusive education as a practice was not being applied consistently at the school.

T1: 'We have a very big problem, the policy from the WCED is that the learner should be assessed alternatively. There is a big thing about inclusion where deaf children and children with Down syndrome ... are supposed to be included within a classroom. For example a Xhosa-speaking child is supposed to be taught and assessed in her mother tongue and that is not happening in our school, that child is disadvantaged. It is not supposed to be happening. I have children who have a visual acuity problem and if a child can't read, we supposed to be reading questions to them and they are supposed to be answering and that is not happening. So as far as assessment is concerned that is why I let them do posters and I let them do oral assessments. I'm trying to ... so lots of children fail because they couldn't read the questions and not all the teachers are patient to read to them.'

\section{Limited training and lack of support for teachers}

T2: 'No remedial support. The onus falls on the teacher. There's lots more that need to be done, I only have, let's say ten months, counting all the holidays. So I have ten months in which to work on the efficacy of their writing. They obviously come from grade 5 with these problems, so basically I'm doing a little bit and sending them off to the next teacher with these problems. I think remedial. I think we should take those children aside and ... have somebody in there to support them.'
T1: 'The teachers have not been trained to do intervention with struggling learners, yet it is expected of them and that is why teachers are upset.'

The teachers reported that there were two levels of challenge. Firstly they do not have access to a remedial teacher, and secondly they do not have the skills to reinforce or develop foundation skills in intermediatephase learners. As there is no remedial teacher at the school, the DoE expects the teachers to provide remedial and additional intervention. Many of the learners who are struggling with reading lack the skills that are taught in the foundation phase. The teachers in this study are intermediate-phase teachers who are not equipped, and do not have the time, to teach the early basic phonics that is the focus in the foundation phase.

\section{Limited reading and writing opportunities}

Although reading and written language is very important for assessment purposes and in determining promotion to the next grade, the learners are not being given sufficient reading and writing opportunities in the classroom. Learners are often given worksheets where they are required to fill in single words; the writing of paragraphs, creative writing stories and compositions are limited. Learners do not have enough opportunity to develop academic literacy through practice.

T2: I would agree with that because we've come to this whole conclusion that we must give worksheets. So they are so inundated with worksheets from grade 1 right through to grade 2, 3, 4 (which is single-word answers) and that I think is where were losing it. Now you will always see my hands are filthy with chalk, because I try to get them to write a lot. There are lots of times where I can just type it out, hand it to them, makes life easy for me they can just fill in oneword answers, but I need them to write more. The syllabus actually does require [it] but because of the loads that we carry these days ... The syllabus is so huge and there are always time constraints and all those things so we sort of try to shorten their writing, rather than to increase it. Ja, because it's easier. So instead of having to mark a long piece you can just tick, it makes things easier for you. Ten years ago I would say children at this school in the grades that I have taught, grade 6 and 7, would write beautiful long pieces. These days I think the children can just about write half a page of cohesive.'

It is a challenge for the teachers to create adequate opportunities to develop writing skills, as the curriculum does not facilitate this.

\section{Disrupted and incompetent teaching}

Another barrier is the disruption of teaching because of lack of teachers or poor teaching skills. Teacher 1 reported that her class was disadvantaged, having had a disrupted year in grade 4 because of poor teaching from two different teachers. She described how she aimed to redress this through the use of various activities, such as drama, oral discussions and debates, when approaching written language tasks. Teacher 2 reported that when approaching a written language task, e.g. creative writing, he spends up to 4 days engaging the class in oral discussions, providing examples, relating the topic to the learners' lives and using the computer to locate and show areas discussed.

T1: 'This is a very difficult class. They had two teachers last year, a very old lady and a gentleman who did very little teaching. So this class is disadvantaged, seriously disadvantaged ... By using drama, they are using their bodies a lot in my class, everything gets dramatised in my class. By enticing them, by using oral work.'

T2: 'They need concrete ... ja. They need to see. And we're fortunate at the moment, we have computers now, up and running for a few months. So if I am going to do something with them and we discuss, even if it's a comprehension, I will always make it so that its geographically located somewhere and it has a issue somewhere so that I will then take them afterwards into the computer room and then, this is only now just for the last couple of weeks because we only got the computers recently.' 
Teacher 2 also asks them to prepare a draft copy of the written work and discusses this with them to give them feedback on their content and grammar. He goes around the class assisting individual learners with written language difficulties (e.g. vocabulary, spelling and grammar problems). The teachers spend much time on redressing the difficulties of previous grades instead of focusing on moving forward with the curriculum. The teacher participants in this study were insightful and concerned - hence their participation in the study and the creative solutions they described to cope with the challenges - but this is not the case for all teachers.

\section{Poor foundation skills}

Early reading and writing skills should be learnt in the foundation phase, i.e. grades $1-3$. Teachers in the foundation phase are trained to teach phonics and early writing conventions. These skills are part of phonological awareness skills (Bus \& Van IJzendoorn, 1999). Teacher 1 reported that if the foundation-phase skills are not acquired, then difficulties arise later in the intermediate phase.

T1: 'In grade 1 there is supposed to be ... a certain set of phonics the child is supposed to know, able to read, able to write and able to recognise. So what happens, children are being shoved over without having satisfied ... that level of proficiency of phonics, reading, writing.

It is very important that learners leave the foundation phase and enter the intermediate phase with solid foundation skills that have initiated the development of reading and written language - but this is often not the case. Learners are passed into the next grade without having achieved the necessary outcomes of that grade. The end result is an accumulation of difficulties over time, as is evident in the large failure rate of learners in the matric examinations. Interventions to boost phonological awareness skills need to be integrated with teaching to improve reading and written language skills (Hatcher, Hulme \& Ellis, 1994).

\section{Large teacher-learner ratios}

T2: 'We need smaller classes to be able to give children individual attention.'

Another barrier that prevents teachers from providing individual instruction to learners is large teacher-learner ratios and overcrowded classrooms. In the present study, there were 48 learners in the grade 5 and 38 learners in the grade 6 classrooms. Teacher 1 reported that she found it very difficult to give the learners individual attention, as there were too many learners in her classroom. Studies have shown that individual assistance or tutoring by teachers to learners who are struggling with reading can improve reading (Wasik \& Slavin, 1993). As reading and written language are closely linked, this would suggest that individual assistance for written language work would also help support written language skills. Furthermore, a study by Jooste (2003) in the Western Cape found that grade 5 learners who came from classes with a lower teacher-learner ratio performed better in reading comprehension tasks than the learners who came from classes with higher teacherlearner ratios.

\section{Language barriers}

T2: 'The township children. So now they come here ... the language barriers were something terrible. So we try to push the parents to rather bring them here in grade 1 so they come right through the system.'

T1: 'The Xhosa-speaking, I can't blame them it's their second language but there are children who have been in our school since preschool that speak beautiful English. But a Xhosa-speaking child that started at our school 2 years ago struggles tremendously with English: When the Xhosa children go back to their homes ... they have restricted contact with English because their parents can't speak English. I think that what needs to happen is that our teachers need to go on a course to learn to speak Xhosa. Paid for by the school or the department. And an intensive one where we can at least converse, so conversational Xhosa, so we can teach in their mother tongue, 'cos that is a problem.'

Both teachers reported that where learners were exposed to English from a young age, e.g. from preschool or grade 1, they are able to cope in the intermediate phase as their English language skills have had time to develop. However, if learners only enter the school in grade 3 or 4 and have not been exposed to English prior to that, there is a language barrier. Not only do these learners need to acquire basic interpersonal communication skills (BICS), they also need to develop cognitive academic language proficiency (CALP) (Cummins, 2008). Teaching and learning is a challenge for all concerned. According to the Education White Paper 6 (DoE, 2001), all learners have different learning needs and the education system is required to meet them.

The Language in Education Policy (LiEP) gives learners the choice of the LoLT (DoE, 1997). Learners in ordinary schools in South Africa have the right to choose any of the eleven official languages as the LoLT and as a learning area from grade 3 onwards (DoE, 1997). Hence, learners may be taught in their mother tongue up to grade 3 , and then have the option of extending the use of their home language into the intermediate phase (DoE, 1997). However, to make it practical, the LiEP makes provision for the consideration of learner numbers when making the choice of the LoLT.

In practice, the SGB decides on the LoLT. Although there have been changes in learner profiles and schools are now linguistically diverse, many schools still choose to have English as the LoLT, as is the case in the school in this study. The teachers in both classrooms speak English and Afrikaans, but cannot speak isiXhosa or any of the other African languages and are therefore not able to communicate with ESOL learners in their mother tongue. Inclusive education is not taking place as the school is not able to support the learners and teachers who are faced with language barriers. There is a need for support for learners to improve their oral English language skills, as this would also assist in promoting their written language development.

\section{No library at school}

The school does not have a library, so learners cannot borrow books. The learners do not go to public libraries either, and many come from homes with few or no books. Many learners therefore do not do any reading at home. The teachers felt that a library at the school would encourage the learners to borrow books and read more, which would enhance their written language skills. According to Harrison (2001), an effective primary school library can have a significant impact on standards of literacy and levels of achievement across the whole curriculum. The absence of a library at the school sends an important and inaccurate message to the learners, that books and reading are not important.

\section{T1: 'Our school doesn't have a library. Our children don't really make use of libraries...'}

\section{B. Barriers at the individual learner level Aversion to writing and reading}

The main barrier at the individual learner level is an aversion to writing and reading. Teacher 2 reported that learners do not like to write or to read outside of school because they have many other interests outside of school (e.g. sport), and also as a result of some of the other barriers described (e.g. no library, weak foundation-phase literacy skills). $\mathrm{He}$ also stated that learners have an aversion to writing and find it difficult to engage in creative writing tasks even in school:

T2: 'I would say it's not as good as their spoken language. Because children by nature are very lazy to write. Aversion to writing, they don't want to write.'

A vicious cycle was described, with learners not wanting to write (and read) because they find it a challenge, and then because of fewer 
opportunities finding it even more challenging, and wanting to do so even less.

T2: 'Our children don't really make use of libraries because they're not interested in reading really.'

\section{Barriers at the social/home community level Lack of parental support}

T1: 'So if you don't have parents' participation, there is nothing you can do ... so unfortunately the parents' participation is not very good within the school in general.'

The teachers reported that many parents do not provide academic support to their children at home and do not attend parent-teacher meetings. Reasons cited for non-attendance of meetings included not having money for transport, not being able to get time off work or not being interested/not understanding the value of meetings. Parents are often not aware of what is happening with their child's learning. They feel that it is the teacher's job to educate their child and do not have an understanding of their role in the education process.

\section{Socio-economic difficulties}

T1: 'Lots of socio-economic barriers. There are many children that I referred to the school psychologist this morning. Seven people are living in a Wendy house, it's overcrowding. Some children have single parents and they are frustrated so it carries over to the child and the child brings it to school. It just affects them psychologically.'

Linked to the lack of support described, many of the learners come from extreme poverty and are disadvantaged in terms of their socioeconomic background. Many of the learners come from homes with single parents, and there is often alcohol and drug abuse, violence and crime in and around the homes. Teacher 2 reported that many learners are left in the care of their grandparents while their parents move out to live in areas closer to their employment. The learners and their families often lead lives where basic needs for survival are the main priority.

\section{Teachers' perceptions of the opportunities to develop the written language of the learners}

Both teachers described a range of opportunities that could help learners to develop their written language. Some of these are opportunities that already exist and might be taken further by the learners, families of learners, teachers and schools. Immediately available opportunities include a feeding scheme, reading books and writing opportunities in the classrooms, peer intervention, various teaching strategies and individual assistance to learners experiencing written language difficulties. These current opportunities are however insufficient and further opportunities are necessary. Opportunities are now presented in turn as they relate to the challenges and to the three different levels identified in the previous section.

\section{A. Opportunities at the school system level}

Clearer, consistent assessment guidelines

It would be helpful for teachers if assessment guidelines and pass/fail criteria were made more explicit and specific training was given in the implementation of these guidelines. The teachers emphasised the need for clear and consistent guidelines to aid in making these decisions.

\section{T1: 'My problem is there is no continuation, it doesn't continue to next} grade. Whatever we do in primary school doesn't get even carried on to high school, and that is a problem with our entire education system. Things we do in primary school, we are still very maturing, doesn't get continued. It stops in high school, a child introduced to a whole new system. And a child gets matriculated and goes to university and it's like a total adjustment. There is no consistency with regard to assessment.'

\section{Training for teachers}

Training workshops for teachers would enable them to update and improve teaching strategies and feel more empowered in their delivery of the curriculum in the present context. Teachers could also learn more about how to provide support to learners who are experiencing difficulties. Workshops might focus on written language and the development and facilitation of literacy, as well as all other subject areas. Wium et al. (2010) developed a support programme for foundationphase teachers to assist them with facilitating listening and language in learners. Enhanced listening and language skills would help learners to cope with numeracy and literacy development in the foundation phase. A support programme for intermediate-phase teachers to assist with the facilitation of foundation skills for reading and writing is needed. The teachers in this study were emphatic in their request for support for helping learners struggling with written language.

T1: 'Never mind the intervention. $M r S$, what does he know about the phonics? He is a grade 6 teacher, he has not been trained, he doesn't know how, and nobody from the department is coming and saying, look guys we running this course, we will give you bursaries, do the course and we will pay for you to do the course so that you are equipped.'

Increased reading and writing opportunities at school Studies by Semke (2008), Hafiz and Tudor (1989) and Tsang (1996) support the importance of reading and writing opportunities in schools. However the learners in this study do not receive sufficient opportunities to practise reading and writing at school. Learners need to be given more reading and writing opportunities at school, to break the cycle of having poor literacy skills, thus finding literacy hard, thus reading/writing even less. This may be achieved by arranging class visits to a public library, and through the use of technology, e.g. cell phones and computers, to stimulate interest in reading and writing. This suggestion is linked to teacher training above, since training might help teachers to create more reading and writing opportunities in the classroom.

T1: 'So I try to play all these games to engage them with the language ... writing games. So I give them lots of opportunities that may not be in the curriculum to write. People think writing is compositions and paragraphs but you can start small. I'm there but I do my own thing. In my class where there are a lot of barriers and problems even if I get the child to write two words or eight words its writing. I go down to the level they are at.'

\section{Teaching strategies}

Improved teaching strategies would help to support all learners with their written work, and in particular those with difficulties. Again, this suggestion is linked to teacher training above since training might help improve teaching and may go some way towards overcoming the disrupted and incompetent teaching described.

T1: 'So I try to teach them clues to help them succeed. Strategies to learn and to succeed and you will be surprised how empowered that child is because he couldn't read and I started him small with small words, little strategies and he is so excited to read now, and he wants his book first so that he can read, ask teacher what ... and praise him again this morning and I'm noticing he is starting to spell words correct. I help them with flash cards, the buddy system

Another example of a creative strategy is the buddy system or peer intervention, which was used frequently in the grade 5 classroom where a stronger learner is seated next to a weaker learner to assist the latter with reading and written language. The teacher felt that this was a beneficial opportunity for learners with difficulties. A study by Simmons, Fuchs, Fuchs, Mathes and Hodge (1995) found that reading comprehension and fluency was significantly higher in learning-disabled and low-performing learners in regular classrooms who received both explicit teaching as well as peer tutoring, than in those who received explicit teaching alone. This suggests that learners who are struggling with reading may benefit from additional peer intervention. 


\section{Remedial assistance}

There is currently a remedial teacher at the school who provides assistance only to the foundation-phase learners. A remedial teacher for the intermediate phase would be a strategy to assist with written language difficulties and enable the learners to achieve the foundation skills in reading and writing that they did not achieve in the foundation phase. Remedial education has been shown to increase levels of school performance and achievement (Sharif al-Shureify, 2004). Children who struggle to learn in the class environment may attend remedial lessons individually or in small groups with other learners who have similar difficulties. The remedial teacher often adapts the teaching materials and tasks to the learners' needs so that the learners may overcome their difficulties and progress at school (Sharif al-Shureify, 2004).

T2: 'I think remedial. I think we should take those children aside and work with those who are ... in the mean while have somebody there to support them. I think they need support. They don't get very much support at home in terms of their writing also.'

\section{Smaller classes}

T2: 'I think we should take those children aside and work with those who need support. Extra teachers, smaller classes would help. I have 38 in my class. I have to pitch everything at an average kind of learner so that the stronger learner will pick it up, the weaker learner hopefully does pick it up. I'll most times spend a few extra minutes with the weaker writer. Then I'll call them up. Some of them don't want to come up, some I'll go to them, I obviously know who they are and I'll spend more time but I can't spend enough time with the weaker ones. We need extra teachers, smaller classes.'

In order to promote effective teaching and learning, a further opportunity would be to build more classrooms and expand the school. The teachers felt that extra teachers and smaller classes would be beneficial in providing more individual assistance to the learners.

\section{Early English exposure}

T2: 'The township children, if they come here from grade 1, or if they come to our school even from preschool ... We have a preschool here, then they are in the system from the beginning. So we try to push the parents to rather bring them here in grade 1 so they come right through the system.'

Teachers felt that if learners were exposed to English from an early age, they would be competent with English by the intermediate phase and the language barriers would be less problematic. Working with teachers to facilitate English language development in the early grades would also be a useful topic to include in teaching training courses and workshops.

\section{Library at school}

T2: 'A library period. That could help, yes.'

The teachers reported that a further opportunity would be setting up a library at the school to promote reading among the learners. A library at the school would encourage the learners to borrow books and participate in more reading, which would ultimately enhance their written language.

\section{B. Opportunities at the individual learner level Reading and writing outside school}

Learners have an aversion to reading and writing. If they were to engage in more reading and writing outside school, their written language skills would improve in the classroom. Ways of encouraging this would be to have parents more involved with reading, co-reading and supervision of reading at home. In the absence of a school library parents should take learners to public libraries to borrow books, thus increasing the opportunities to practise reading skills.
T1: 'I believe strong, I told my learners and parents, and I'm not a magician either, I don't make things happen. We need to work together in order to succeed.'

T2: 'Up till about ten years ago, I had grade 6s and I encourage reading all the time, who would bring in the books, they come with their library books and for the first half-an-hour of the day they would read. In my class now, there are only two children who are coming with their library books to school. So the rest of them are not really interested in reading.'

\section{Interesting and relevant books}

Teacher 2 reported a need for books that interest the learners and are related to their life and culture. The learners need to be encouraged to see the relevance of reading in their lives.

T2: 'But also the books should be entertaining enough and new enough with new ideas. Not your older books. It must be within their life, world, rather than something that is far removed.'

This should be applicable to both school reading materials and books that the learners read outside of school.

\section{Opportunities at the social/home community level}

Increased parental support and safe, nurturing home environments The teachers felt that learners need to have a safe, nurturing home environment in order to support them and enable them to do well at school. Both teachers believed that the learners need support from home, particularly from their parents. Parental support with homework is linked to increased academic achievement at school (Steinberg, Lamborn, Dornbusch \& Darling, 1992), and conversely a lack of support from home has a negative effect on learners' written language skills and overall academic performance.

T2: '.. first of all a loving environment. A warm nurturing environment. Parents who are interested, actually interested in what their children are doing. Any child who has the interest and support of the parent does better than the child who doesn't have any interest.'

\section{Feeding scheme at school}

T1: '75\% of my class is depending on the school feeding scheme.'

Teacher 1 ensures that $75 \%$ of the learners in her class receive a meal from the school feeding scheme. They need adequate nutrition to be able to learn. The school has put in place basic support in addition to academic support, as learners who do not bring lunch from home are provided with a full meal at lunchtime. This is an example of a way in which the school has begun to address a barrier at the social/home community level.

Table II provides a summary of the challenges and opportunities at the school system level, individual learner level and social/home community level as identified by the participants in this study. Many of the opportunities suggested may help in addressing more than one barrier, e.g. further training for teachers may be one way of addressing the current issues regarding lack of support and training for teachers, but it would also help to develop teachers' knowledge of how to create more opportunities for literacy development, increase weak foundation skills and help teachers to cope better with language barriers.

\section{Discussion}

In-depth semi-structured interviews with two intermediate-phase educators revealed their concerns about the written language of the learners in their classrooms. In both grade 5 and 6 classrooms it was found that the learners were experiencing difficulties with written language expression. According to the teachers, $70 \%$ of the learners in the grade 5 classroom were not able to meet the writing outcomes for their grade, while in the grade 6 classroom $50 \%$ of the learners were struggling to achieve the writing outcomes. The extent of the difficulties described fits 


\section{Table II. Barriers to and opportunities for written language development}

\section{School system level \\ Barriers}

Lack of inclusive education

Limited training and lack of support for teachers

Limited reading and writing opportunities

Disrupted and incompetent teaching

Poor foundation skills

Large teacher-learner ratio

Language barriers

No library at school

\section{Individual learner level}

\section{Barriers}

Aversion to writing and reading

\section{Social/home community level}

Lack of parental support

Socio-economic difficulties

\section{Opportunities}

Clearer consistent assessment guidelines

Training for teachers

Increased reading and writing opportunities at school

Teaching strategies

Remedial assistance

Extra teachers/smaller classes

Early exposure to English

Library at school

\section{Opportunities}

Reading and writing outside school

Interesting and relevant books

\section{Opportunities}

Increased parental support and safe, nurturing home environments Feeding scheme at school with other studies, both local (e.g. O'Connor \& Geiger, 2009; DOE, 2008) and international (e.g. Mullis et al., 2007). Written language difficulties are not the only area of concern. Language and communication lie at the heart of the difficulties described. Written language is a very tangible way of evaluating language, a window into the child's stored knowledge of his/ her languages (Bishop \& Clarkson, 2003).

Both teachers emphasised that the difficulties experienced by the learners are directly related to problems in the school system. The learners were described as products of a defective system rather than being the problems themselves. The DoE in South Africa has put forth the policy of inclusive education for all learners in ordinary schools. It has been acknowledged that learners come into classrooms with a range of barriers, and schools need to accommodate these barriers and support learners. However with a variety of challenges in the school system itself, schools and teachers are often ineffective in supporting learners with barriers, and this results in a failed school system.

Eight main barriers that impinge on learners at the school system level were identified. These included aspects such as teachers having received insufficient training and therefore not being able to support the learners effectively, a lack of resources at the school, and disrupted and incompetent teaching. While most of the barriers identified centred at the school level, another barrier was at the social/home community level where difficulties like lack of parental support and socio-economic hardships were seen to impact on the learners. It is interesting that only one barrier was identified at the level of individual learners: their aversion to reading and writing. While this problem may be sited within the learners themselves, it is clear that the aversion is the end result of the other barriers described. If the school system were improved, children would have more opportunities to develop their reading and writing, and ultimately be better at it and possibly enjoy it more.
Figure 1 provides a graphical representation of the factors promoting written language: a model that integrates the school systems, home/ social community, and learners as well as any additional other support that will promote the written language development in ordinary linguistically diverse classrooms.

For written language to develop successfully, the school system, home/ social community and individual learners need to work together to promote written language development. The school system has to be an effective, inclusive system. It needs to provide effective opportunities to promote written language development among learners, as well as taking into account and breaking down barriers that may arise. The home/social community needs to be involved in education. Parents need to create a safe home environment, as well as support written language and learning activities at home. Since literacy is not established in the community, caregivers and others in the community require support in how to embed such practice. Learners also need to be motivated towards learning and developing their written language.

Teachers in this study frequently mentioned the need for remedial support, and having a remedial teacher in the school (albeit for the foundation phase) has made them familiar with the role of such a professional. SLTs also have an important contribution to make in such contexts. The teachers in this study did not directly mention the role of the SLT - and may in fact have had little experience of their role - but in many places they did describe a potential role that SLTs would be able to fill, e.g. offering small-group support, developing phonological awareness skills, and developing a solid basis of spoken language.

The barriers described by the teachers and presented in this paper are more complex than a series of isolated problems since they interact with each other in multiple, complex ways. This complexity is shown, for

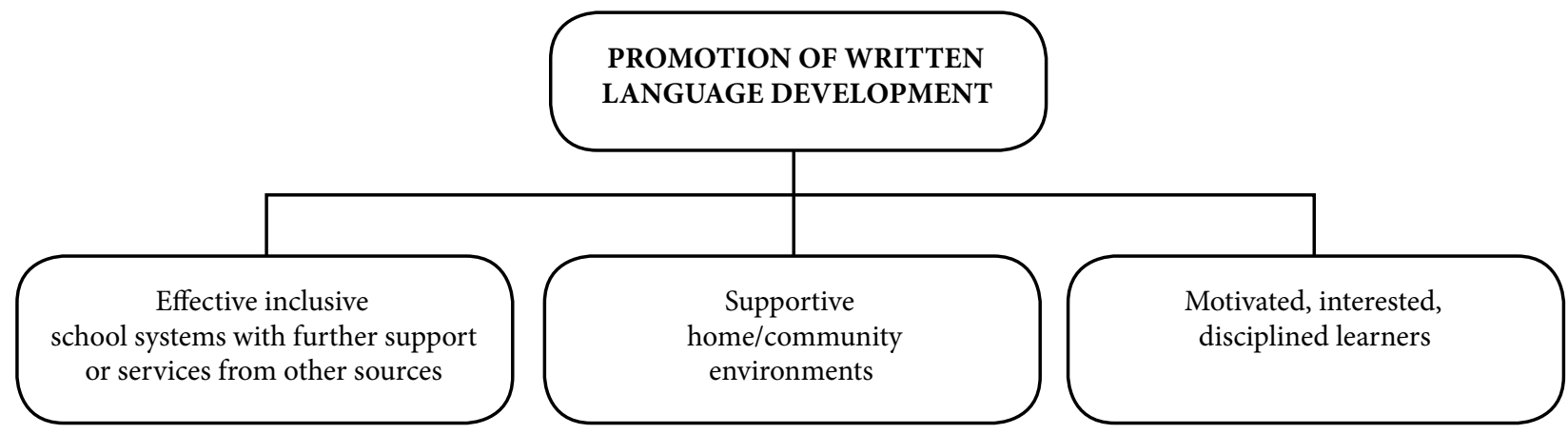

Fig. 1. Summary of factors promoting written language development in ordinary linguistically diverse classrooms. 
example, in Table II, where opportunities to overcome barriers do not necessarily map from one to the other in a neat way. Rather, it has been found that there will be several ways of addressing a barrier, and one opportunity for change may in turn impact on several of the identified barriers. The need for teacher training was frequently emphasised in the interviews, and supports the work carried out by Wium et al. (2010) where SLTs provided support to teachers focusing on language and literacy development. Internationally, SLTs have an established role in the development of literacy - of which writing is a part - due to the strong connection between oral and written language (ASHA, 2001; Ehren \& Whitmire, 2009; Justice, Invernizzi \& Meier, 2002).

\section{Conclusion}

The results of this study indicated that teachers were very concerned about the written language development of the learners in their classrooms. Multiple barriers impede written language development. These range from limited reading and writing opportunities, limited training of teachers, language barriers, lack of resources in the school, unsafe home environments and lack of parental support to poor foundation skills in reading and writing and limited reading and writing outside of school. While the teachers spoke about the problems of the individuals in their classrooms, they presented a broader view of the learners' difficulties contextualised against a backdrop of historical inequalities and social inadequacies. They suggested that to understand the difficulties you have to look beyond the learners as the site of the problem, and understand the system in which they are being educated and the context more generally.

Immediately available opportunities include a feeding scheme, reading books and writing opportunities in the classrooms, and various teaching strategies to assist learners who are experiencing written language difficulties. These opportunities are insufficient, however, and further opportunities are necessary. Further opportunities include training for teachers (e.g. around assessment), remedial assistance, a school library, a lower teacher/learner ratio, providing interesting and culturally related reading books, greater parental support and involvement, and safe, nurturing home environments. The school, home/social community and learners collectively play a role in the development of written language and the overall education of the learners. A joint partnership between the school and home is needed to assist and support learners to achieve the writing outcomes of their grade and ensure future success in their academic careers. Furthermore, there is a need for SLTs in ordinary schools in South Africa to support the crisis of written language. Currently, however, there are no posts, so even though SLTs may have the expertise, they are unable to provide the necessary support required in ordinary linguistically diverse classrooms in South Africa.

Implications for SLTs in ordinary schools in South Africa In South Africa, there are no DoE posts for SLTs in ordinary schools. SLTs are employed in government hospitals and special schools where they assess and treat learners with verbal and written language difficulties (Overett \& Kathard, 2006). However, it is acknowledged that there is a need for SLTs in South Africa to expand their services to learners in ordinary schools who are not developing age-appropriate literacy and numeracy skills (Du Plessis \& Louw, 2008; Wium, 2010). There is a critical need for SLTs as there is a large at-risk population of learners.

The SLT's role may extend beyond this in linguistically diverse classrooms, where there is a need to differentiate between children who are struggling to learn because of second-language difficulties and those who have learning problems as a result of delayed language development and phonological awareness skills. SLTs are challenged to find ways to work in the ordinary classroom in South Africa as there is a need to assist learners who may present with slow development rather than disorders (Kathard \& Pillay, 2006). Lewis (2004) emphasised the need for SLTs to expand their support to learners in ordinary schools who are not developing grade-appropriate literacy and numeracy skills. SLTs are uniquely qualified to help individual learners achieve literacy, and also be part of the team associated with enhancing literacy among all the learners in schools (Gottfred, 2008). In the USA, schools have teams consisting of SLTs, reading specialists, teachers and remedial teachers who assist learners with reading difficulties, from preschool level, by providing intensive reading programmes (Ciampaglio, 2008). These programmes have been found to enhance literacy (Tsang, 1996).

In South Africa, it is imperative that SLTs be part of the team in ordinary schools to promote and enhance literacy, and that an SLT's role in this context be defined. ASHA (2001, p. 356) described the role of SLTs with regard to literacy development across the school curriculum in all grades at primary schools in the USA:

- preventing written language problems by fostering language acquisition and emergent literacy support

- identifying children 'at risk' for reading and writing problems and providing early intervention to these children

- assessing reading and writing in learners

- providing intervention and documenting outcomes for reading and writing

- assuming other roles such as providing assistance to teachers, parents and learners

- advocating for effective literacy practices and advancing the knowledge base

- providing support to teachers and learners in the classrooms and across the school system.

SLTs in the South African context may have additional contributions to make. For example:

- SLTs together with other professionals should be involved in policymaking decisions regarding language across the school systems, e.g. bilingual education, learning in ESOL, as well as motivating for SLT posts in ordinary schools in South Africa.

- SLTs should collaborate with teachers in identifying children who require speech and language intervention, and then in providing early language support to all learners to prevent speech and language difficulties.

- SLTs should assist teachers in ordinary classrooms in the planning and teaching of language lessons. This collaboration with teachers should

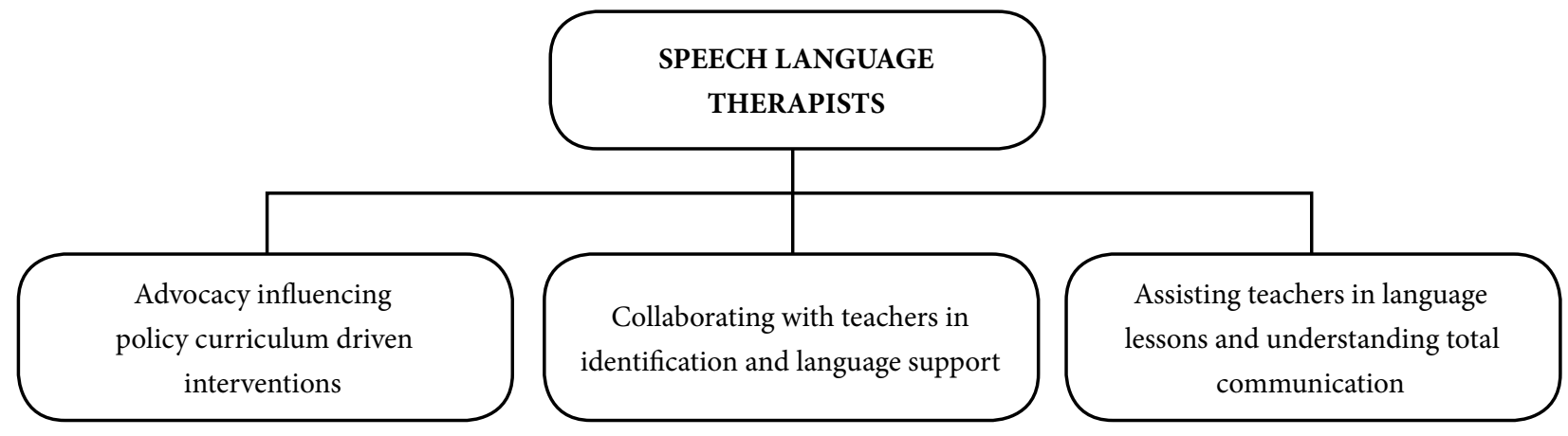

Fig. 2. Proposed role of SLTs in ordinary linguistically diverse South African classrooms 
strive to promote an understanding of the total communication resource that learners bring to the classroom rather than only focusing on whether a learner can speak and write English.

Figure 2 summarises the proposed role of SLTs in ordinary linguistically diverse South African classrooms.

The teachers interviewed in this study described the systemic failure that has led to the failure of the learners in their classrooms. In South Africa, SLTs may have an important role not only in supporting individual learners, their families and educators in their language and literacy learning, but also through working as change agents who strive to improve the system and create a more optimal environment in which all learners can develop their literacy.

Acknowledgements. The authors sincerely thank the teachers and the school principal for their assistance throughout this project. We would like to acknowledge the National Research Fund for their financial assistance (Thuthuka Project: Enhancing communication in classrooms - Kathard 2006 - 2011).

\section{References}

American Speech-Language-Hearing Association (2001). Role and responsibilities of speech-language therapists with respect to reading and writing in children and adolescents. ASHA, 21(suppl.), 17-28, Rockville, MD.

American Speech-Language-Hearing Association (2002). Designing and implementing an early literacy screening protocol: suggestions for the speech-language pathologist. Language, speech and hearing services in schools, 33, 84-101.

Bishop, D.V.M., \& Clarkson, B. (2003). Written language as a window into residual language deficits: a study of children with persistent and residual speech and language impairments. Cortex, 39(2), 215-237.

Botes, H., \& Mji, A. (2010). Language diversity in the mathematics classrooms: does a learner companion make a difference. South African Journal of Education, 30(1), 123-138.

Bus, A.G., \& Van IJzendoorn, M.H. (1999). Phonological awareness and early reading: a meta-analysis of experimental training studies. Journal of Educational Psychology, 91(3), 403-414.

Centre for Evaluation and Assessment (2006). PIRLS of Wisdom: The what, where, when and how of the International Reading Literacy Study in South Africa. Pretoria: University of Pretoria.

Ciampaglio, S. (2008). Teamwork helps struggling readers: response to intervention program pairs SLP, reading teachers. ASHA leader, September, 23, 2008.

Cummins, J. (2008). BICS and CALP: Empirical and theoretical status of the distinction. In B. Street

\& N.H. Hornberger (Eds.), Encyclopaedia of Language and Education (2nd ed.), Vol 2: Literacy (p.71-83). New York: Springer.

Department of Education (1997). The language in education policy and national curriculum statement. Retrieved on 22 September 2009 from http://www.thuthong.doe.gov.za/getlanguages/languages/FAQ/ tabloid $/ 2087$

Department of Education (2001). Education White Paper 6: special needs education - building an inclusive education and training system. Pretoria: Department of Education.

Department of Education (2008). National reading strategy. Pretoria: Department of Education.

Du Plessis, S., \& Louw, B. (2008). Challenges to preschool teachers in learner's acquisition of English as language of learning and teaching. South African Journal of Education, 28(1), 53-75.

Ehren, B.J., \& Whitmire, K. (2009). Speech-language pathologists as primary contributors to response-tointervention at the secondary level. Seminars in Speech and Language, 30(2), 90-104.

Gottfred, K. (2008). On language and literacy. ASHA Leader, September, 23, 2008.

Gouws, E., \& Dicker, A.M. (2006). Onderwysers se belewing van indiensopleiding met betrekking tot die hersiene nasionale kurrikulum verklaring: 'n gevallestudie. Tydskrif vir Geesteswetenskappe, 46(4), 416-427.

Hafiz, F.M., \& Tudor, I. (1989). Extensive reading and the development of language skills. ELT Journal, $43(1), 4-13$

Harrison, K. (2001). Policy making and development planning for the primary school library. Schoo libraries, literacy and reading. Retrieved on 13 May 2009 from http://www.literacytrust.org.uk

Hatcher, P.J., Hulme, C., \& Ellis, A.W. (1994). Ameliorating early reading failure by integrating the teaching of reading and phonological skills: the phonological linkage hypothesis. Child Development, 65(1), $41-57$.

Heugh, K. (2000). The case against bilingual and multilingual education in South Africa. PRAESA occasional papers No. 6. Cape Town: PRAESA.

Jooste, N. (2003). Learning through a second language: a comparative study of the performance in reading comprehension between first-language English learners and second-language English, first-language IsiXhosa learners at the grade 5 level. Unpublished M.Sc. Speech-language Pathology dissertation. University of Cape Town.

Justice, L.M., Invernizzi, M.A., \& Meier, J.D. (2002). Designing and implementing an early literacy screenin protocol: Suggestions for the speech-language pathologist. Language, Speech and Hearing Services in Schools, 33, 84-101.

Kapp, R. (2004). Reading on the line. An analysis of literacy practices in ESL classes in a South African township school. Language and Education, 18(3), 246-263.

Kathard, H., \& Pillay, M. (2006). Practice innovations: language practitioners in (South African) classrooms. International Journal of Learning, 13, 3-13.

Lewis, F. (2004). Speech therapists in schools: curriculum integration and curriculum innovationchallenges to the school speech-language therapist of today. Communiphon, Winter 2004 (337), 36-37.

Locke, A., Ginsborg, J., \& Peers, I. (2002). Development and disadvantage: implications for the early years and beyond. International Journal of Language and Communication Disorders, 37(1), 3-15.

Maxwell, D.L., \& Satake, E. (2006). Research and statistical methods in communication sciences and disorders. Canada: Thomson Delmar Learning.
Mullis, I.V.S., Martin, M., Kennedy, A.M., \& Foy, P. (2007). IEA’s progress in international reading literacy study in primary schools in 40 countries. Boston College, Boston, M.A.: TIMSS \& PIRLS Internationa Study Centre.

Nelson Mandela Foundation (2004). How far have we come? Reflections from the first 10 years of basic education transformation. Johannesburg: Nelson Mandela Foundation.

Nicolosi, L., Harryman, E., \& Krescheck, J. (1989). Terminology of communication disorders: Speechlanguage-hearing (3rd ed.). Baltimore: Williams \& Wilkins.

O' Connor, J., \& Geiger, M. (2009). Challenges facing primary school educators of English second (or other) language learners in the Western Cape. South African Journal of Education, 29(2), 253-269.

Overett, W., \& Kathard, H. (2006). Profiles of outpatient speech-language therapy and audiology clients at a tertiary hospital in the Western Cape. South African Journal of Communication Disorders, 53, 49-58.

Patton, M.Q. (2002). Qualitative research \& evaluation methods (3rd ed.). California: Sage Publications.

Pluddemann, P., Xola M., \& Mahlahela-Thusi, B. (2000). Problems and possibilities in multilingual classrooms in the Western Cape. PRAESA occasional papers No. 2. Cape Town: PRAESA.

Rubin, H.J., \& Rubin, I.S. (2005). Qualitative interviewing: The art of hearing data (2nd ed.). California: Sage Publications, Inc.

Scherman, V., Van Staden, S., Venter, E., \& Howie, S. (2008). South African performance in PIRLS 2006 a national crisis. Symposium Papers: National Reflections on International comparative Achievement Studies (Part 4). Pretoria: University of Pretoria.

Semke, H.D. (2008). Effects of the red pen. Foreign Language Annals, 17(3), 195-202.

Sharif al-Shureify, M.A. (2004). Panacea for under-achievement in schools? Yemen Times, 13(745), 1-3.

Simmons, D.C., Fuchs, L.S., Fuchs, D., Mathes, P., \& Hodge, J.P. (1995). Effects of explicit teaching and peer tutoring on the reading achievement of learning disabled and low performing students in regular classrooms. Elementary School Journal, 95(5), 387-408.

Sofaer, S. (2002). Qualitative research methods. International Journal for Quality in Health Care, 14, 329-336. Soudien, C. (2008). Misrecognition: policy in pursuit of justice? Keynote address to the EASA/OVSA Conference, January 2008, 1-11. Langebaan: EASA/OVSA.

Steinberg, L., Lamborn, S.D., Dornbusch, S.M., \& Darling, N. (1992). Impact of parenting practices on adolescent achievement: authoritative parenting, school involvement and encouragement to succeed. Child Development, 63(5), 1266-1281.

Tsang, W.K. (1996). Comparing the effects of reading and writing on writing performance. Applied Linguistics, 17(2), 210-233.

UNESCO (2010). Equal education statement on 2009 matric results. Cape Town: University of Cape Town Retrieved on 27 January 2010 from http://blogs.uct.ac.za/blog/educblog/2010/01/08/equal-educationstatement

Walton, J.R. (2002). Global-mindedness and communication competency: teachers in multicultural classrooms. Journal of Research on Minority Affairs, April, 19, 50-81.

Wasik. B.A., \& Slavin, R.E. (1993). Preventing early reading failure with one-to-one tutoring: a review of five programs. Reading Research Quarterly, 28(2), 178-200.

Wium, A.M. (2010). The development of a support programme for foundation phase teachers to facilitate listening and language for numeracy. Postgraduate doctoral thesis. University of Pretoria: Electronic Theses and Dissertations. Retrieved on 25 June 2010 from www.upetd.up.ac.za/thesis/available/etd05152010-233034/

Wium, A.M., Louw, B., \& Eloff, I. (2010). Speech-language therapists supporting foundation-phase teacher with literacy and numeracy in a rural and township context. South African Journal of Communication Disorders, 57(1), 14-21.

World Medical Association (2008). Declaration of Helsinki - Ethical Principles for Medical Research Involving Human Subjects. Retrieved on 8 March 2010 from http://www.wma.net.

\section{Appendix A. Interview schedule: Teachers}

\section{Exploratory question}

Tell me about the expectations of written language for grade 5/6.

\section{Probes and possible follow-up questions}

What kinds of difficulty or challenges were encountered? How do you approach written language tasks in your class? How important is the oral versus written language in the class? What are the pass/fail criteria in the grade?

How important is written language in the assessments of the learners in the different learning areas?

Tell me about the oral and written communication of the learners. What are the quality and style of the written language of the learners, e.g. vocabulary, grammar, spelling, punctuation, narration?

What were the consequences?

How do you try to support the learner with written language difficulties?

What was the outcome?

What are the continuing barriers?

What are some support strategies that may assist the learners at school?

What are the support strategies at home that may assist the learners? 